\title{
A qualitative exploration of teachers' perspective on smartphones usage in higher education in developing countries
}

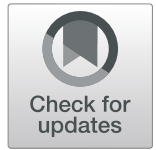

Shakeel lqbal ${ }^{*}$ (D) and Zeeshan Ahmed Bhatti ${ }^{2}$ (D)

\author{
* Correspondence: siqbal@iqraisb. \\ edu.pk \\ ${ }^{1}$ Department of Business \\ Administration, lqra University \\ Islamabad Campus, Islamabad, \\ Pakistan \\ Full list of author information is \\ available at the end of the article
}

\begin{abstract}
Recently, Smartphone sales have surpassed the sales of all other computing devices including desktops, laptops and tablet PCs. Moreover, Smartphones have become a primary device to access the Internet as well as the most commonly used infotainment gadget among the Generations $Y$ and $Z$ (those born in 80s and 90s). Despite this widespread adoption of Smartphones among the youth, its usage in higher education is still a novice idea specifically in developing countries. This study is aimed at capturing the views of faculty members regarding usage of Smartphones for promoting learning at the tertiary level. In-depth interviews of 22 faculty members from different academic departments were conducted for this purpose. Responses of the interviewees were recorded which were later transcribed and analyzed to draw inferences. Results of this study indicate that the faculty members considered Smartphones to be an effective medium for off-campus learning and communication with peers and students. They also considered Smartphones suitable for explaining complex topics to their students as audio-visual content available over the Internet can easily be shared. However, majority of the respondents were skeptical about using Smartphones for educational purposes as they considered them to be a source of distraction, wastage of time, technostress, and emotional detachment. Moreover, they reported small size of both the screen and keyboard as an important limiting factor undermining the effective use of Smartphones in education. Lack of training and support, lack of technical knowledge and background, excessive work load and lack of incentives for using technology in education were reported as major barriers in adoption of Smartphones in higher learning landscape.
\end{abstract}

Keywords: Smartphones, Higher education, M-learning, Teachers' perceptions, Barriers

\section{Introduction}

A Smartphone is an advanced technology gadget that has all mobile phone features as well as computer capabilities. Litchfield (2010) defined a Smartphone as a mobile device that runs an open operating system and is permanently connected to the Internet. Buck, McInnis, and Randolph (2013) defined Smartphone as an innovation that is

(c) The Author(s). 2020 Open Access This article is licensed under a Creative Commons Attribution 4.0 International License, which permits use, sharing, adaptation, distribution and reproduction in any medium or format, as long as you give appropriate credit to the original author(s) and the source, provide a link to the Creative Commons licence, and indicate if changes were made. The images or other third party material in this article are included in the article's Creative Commons licence, unless indicated otherwise in a credit line to the material. If material is not included in the article's Creative Commons licence and your intended use is not permitted by statutory regulation or exceeds the permitted use, you will need to obtain permission directly from the copyright holder. To view a copy of this licence, visit http://creativecommons.org/licenses/by/4.0/. 
always being upgraded with new features to enhance its capacity and usefulness. Trinder (2005) indicated a wide range of functions offered by Smartphones that include audio and video recording/streaming/calling, Internet access, emailing and messaging via multimedia messaging service (MMS) and short messaging service (SMS) options. It is a disruptive technology having a huge impact on societies, since it has transformed the way in which people interact, socialize, entertain and organize their tasks (Alexander, 2004). According to Park (2011) latest range of Smartphones are versatile and ubiquitous in nature and their latest features (such as access to social media sites and applications) carry tremendous educational potential.

The functionality of Smartphones is rapidly increasing on one hand while the cost of these devices is decreasing on the other, thus making them more affordable than any other mobile device. Even in the developing countries they are becoming increasingly popular (Iqbal, Khan, \& Malik, 2017; Iqbal \& Qureshi, 2012; Kibona \& Rugina, 2015). Worldwide statistics indicate that majority of Smartphone users are young people mostly belonging to Generation Z (also known as "Digital Natives" - those born in the 1990s). These Digital Natives have certain unique characteristics; one of which is their increased dependence on technology. According to Carr (2011), present breed of university students rely heavily on technology: they don't read front to back from a book, they read from the screen and get information through different referenced materials using the Internet acting as "skilled hunters". The learning requirements of these digital natives are different compared to their predecessors, therefore it is imperative that present day teachers/instructors are aware of these requirements and are able to use latest technologies for developing innovative pedagogies to meet the distinct learning needs of new generation.

Despite worldwide popularity and adoption of Smartphones among the youth, present day educators seem to be divided on the issue of using Smartphones in formal and informal education. Some consider them a useful tool to facilitate learning, while to others consider them to be a source of distraction. On account of these differences it is important to examine the perceptions of educators (especially in developing countries like Pakistan) with respect to usage of Smartphones in higher education context.

\section{Literature review}

Using Smartphones for educational purposes fits into the realm of mobile learning (or Mlearning) paradigm which is considered to be an extension of electronic learning (or Elearning). M-learning is a medium of learning that uses mobile devices to create educational opportunities and deliver information (Brown, 2005). According to Schuler, Winters, and West (2012), M-learning is the process of learning mediated by handheld devices such as Smartphones, tablet computers, and gaming consoles. There are several terms associated with M-learning such as ubiquitous learning (U-learning), handheld learning, anywhere/anytime learning and personalized learning (Mehdipour \& Zerehkafi, 2013). Mlearning is defined by MOBIlearn guidelines as any sort of learning that happens when the learner is not at a fixed predetermined location, or learning that happens when the learner takes advantage of the learning opportunities offered by mobile technologies (O'Malley et al., 2005). The increased computing capabilities of mobile devices and their 
ubiquity have created significant interest among the educators to use them in promoting formal and informal learning.

Smartphones can be considered an effective tool to promote collaborative learning; a form of learning which has gained popularity among the academic community in recent times. In collaborative learning, students share their knowledge and experiences with each other as well as they mutually learn and teach (Panitz, 1996). According to Lipponen (2002), students in a collaborative environment are able to gather substantial information which they use to generate new ideas for effective learning. This learning methodology is useful in promoting critical thinking as well as giving confidence to the students to express their ideas and opinions (Angeli, Valanides, \& Bonk, 2003; Lantz, 2010). It also helps the students in gaining deeper understanding of the subject matter, allowing them to relate new information with their existing knowledge (Kennedy, G.,\& Cuts, Q., 2005). Collaborative learning is very useful in promoting active learning in which students actively participate in classroom learning rather than acting only as passive listeners. Research has shown that active learning process is useful in enhancing knowledge as well improving academic performance (Yoder \& Hochevar, 2005). It is also asserted that combining technology with collaborative learning can further boost the academic performance of students (Awedh, Mueen, Zafar, \& Manzoor, 2015).

Recent developments in the fields of computing, networking, and telecommunication have led to the evolution of new learning paradigms: e-learning to m-learning to $\mathrm{u}$ learning. We have already discussed m-learning whereas U-learning is defined as:

"a learning paradigm which takes place in a ubiquitous computing environment that enables learning the right thing at the right place and time in the right way". (Yahya, Ahmad, \& Jalil, 2010, p.4).

The main objective of U-learning is to accommodate the learners according to their learning style by offering them required information anywhere/anytime. Yahya et al. (2010) proposed the following five characteristics of U-learning: permanency (information is available as long as the user desires), immediacy (user can immediately access the information when needed), accessibility (the information is available 24/7), contextawareness (the learning environment can be modified according to the situation of learners), and interactivity (effective and efficient interaction between peers, teachers, and experts).

Several studies conducted in various diverse contexts explore teachers' perspective towards using Smartphones and smart mobile devices (SMDs) in higher education. Shraim and Crompton (2015) conducted a study in Palestine to investigate the perceptions of faculty towards using SMDs in teaching and reported that despite widespread adoption of the SMDs, faculty was mostly unaware of various functionalities of SMDs that can assist them in teaching. Miglani and Awadhiya (2017) examined m-learning readiness and perceptions of teachers of Open Universities of five Commonwealth Asian countries (Pakistan, India, Malaysia, Bangladesh and Sri Lanka) and reported that majority of the teachers had Internet-enabled mobile phones as well as they were using them for browsing, sending and receiving emails, downloading mobile apps and social networking. However, majority of respondents in their study were not using their mobile phones for downloading and reading e-books, making video calls, downloading 
audio podcasts, and blogging. In another study conducted on teachers' acceptance of SMDs in South Korea, Leem and Sung (2019) found that teacher's beliefs were the main predictor of adoption of SMDs for educational purposes. Their study suggested to reduce the teachers' negative beliefs towards SMDs to promote adoption of SMDs for teaching and learning. Alzubi (2019) conducted a study in Saudi Arabia to explore teachers' perceptions towards using Smartphones in teaching English as a foreign language and reported that majority of teachers were using Smartphones for universityrelated work such as accessing the Internet, sending and receiving emails, and using various educational applications. This study, however, reported only one barrier in using Smartphones for educational purposes and that was student distraction.

Existing literature on this topic indicates that very few studies have been conducted in Pakistan on Smartphone adoption in higher education from teachers perspective, although several studies have been conducted on this topic from the students perspective (e.g. see Iqbal and Qureshi (2012); Iqbal et al. (2017); Khan, Khalid, and Iqbal (2019) and Nand, Pitafi, Kanwal, Pitafi, and Rasheed (2019)). In one of the studies conducted by Butt and Qaisar (2017), readiness of Pakistani University teachers and students towards m-learning was investigated and it was reported that almost all the male teachers and $75 \%$ of the female teachers surveyed were ready to use mobile phone as a learning tool; as well as they were ready to invest time in learning mobile technologies. Rahman and Hameed (2018) conducted a qualitative exploratory study in Pakistan to investigate teaching and learning with Smartphones and reported them to be an ideal medium for conducting collaborative learning exercises that can eventually improve student engagement. However, student distraction, loss of control over class, and wastage of time were reported to be the major risks associated with usage of Smartphones for teaching and learning.

There is an extensive body of literature that suggests plethora of opportunities offered by $\mathrm{m}$-learning paradigm. However, very few studies have been conducted to explore the perceptions and adoption of m-learning among teachers of higher learning institutions specifically in developing countries. A general observation is that teachers in higher learning institutions in developing countries are reluctant to use Smartphones for teaching and learning activities, therefore there is a need to explore the underlying reasons for this phenomenon. This study is conducted to answer the research questions specified in Table 1:

\section{Methodology}

Qualitative method is adopted as a mode of inquiry for this study, since it is most suitable for conducting in-depth interviews. On the contrary quantitative survey methods are not suitable for describing the interaction between perceptions and actions (Brookhart \& Freeman, 1992; Richardson, 1996. Although in a qualitative research the number of participants is small (Russell \& Gregory, 2003), in-depth interviews are helpful in exploring those phenomena which are otherwise not possible using a quantitative research design (Slauenwhite \& Simpson, 1998).

\section{Sampling and sample size}

In this study, semi-structured interviews were conducted from 22 teachers of higher learning institutions. This sample size is in line with the recommendations of Marshall, 
Table 1 The interview questions and purpose of each question

\begin{tabular}{|c|c|}
\hline Interview Questions & Purpose \\
\hline $\begin{array}{l}\text { 1. Are you currently using a Smartphone? If yes, please } \\
\text { indicate the tasks that you normally perform using } \\
\text { your Smartphone? }\end{array}$ & $\begin{array}{l}\text { The purpose of this question is to know the } \\
\text { commonly used features of Smartphones amongst } \\
\text { the university faculty. }\end{array}$ \\
\hline $\begin{array}{l}\text { 2. Have you ever used a Smartphone in your course } \\
\text { (or teaching) to engage students? If yes, please } \\
\text { describe how? }\end{array}$ & $\begin{array}{l}\text { This question probes the academic use of } \\
\text { Smartphones among the university faculty members. }\end{array}$ \\
\hline $\begin{array}{l}\text { 3. Please comment on the effectiveness of using } \\
\text { Smartphones in education. Can they be a tool to } \\
\text { enhance student learning? Do you think it is a good } \\
\text { idea to promote learning using Smartphones? Why or } \\
\text { why not? }\end{array}$ & $\begin{array}{l}\text { This question is asked to capture the perceptions of } \\
\text { faculty members about the effectiveness of using } \\
\text { Smartphones in promoting learning among the } \\
\text { students. }\end{array}$ \\
\hline $\begin{array}{l}\text { 4. Do you think there are any negative effect(s) } \\
\text { (disadvantages) of using Smartphones in education } \\
\text { related activities? }\end{array}$ & $\begin{array}{l}\text { The purpose of this question is to know the } \\
\text { apprehensions of faculty members in using } \\
\text { Smartphones in Higher Education }\end{array}$ \\
\hline $\begin{array}{l}\text { 5. Please indicate a few barriers that restrict the } \\
\text { teachers to use Smartphones in promoting learning } \\
\text { in higher education institutions. }\end{array}$ & $\begin{array}{l}\text { This question is helpful in identifying some of the key } \\
\text { barriers restricting adoption of Smartphones among } \\
\text { the university faculty for educational purposes. }\end{array}$ \\
\hline
\end{tabular}

Cardon, Poddar, and Fontenot (2013), who after conducting an examination of many qualitative interviews in the field of Information Systems, recommended 20 to 30 interviews for grounded theory qualitative studies. All the respondents were selected on the basis of purposive sampling technique which is defined as selecting units (e.g., individuals, groups of individuals, or institutions) based on specific purposes associated with answering a research study's questions (Teddlie \& Yu, 2007). This sampling technique is useful for current study, as it helps the researchers to recruit the key informants who have the specific knowledge of the phenomenon under investigation (Schutt, 2006); as well as it provides greater in-depth information compared to other probability sampling techniques. The respondents belong to Islamabad:the capital of Pakistan and a multicultural city having a diverse population from all over the country. To gather the required information, semistructured interviews were conducted from 22 full time employed faculty members belonging to five different departments (i.e., Business Administration, Computer Science, Engineering, Social Sciences and Arts \& Fashion Design) of a private sector university located in Islamabad. The university has around 130 full time faculty members and its student body consists of around 4000 students. Demographic information pertaining to gender, education, department and years of teaching experience of the interviewees is shown in Table 2:

\section{Interview settings}

The selected respondents were contacted via phone and email. The purpose of study was explained to them and appointments for interviews were sought according to their convenience. The interviews were conducted in office environment during the months of March and April 2019. Express consent was solicited from the respondents for recording their interviews. The duration of each interview varied between 20 to $30 \mathrm{~min}$. The responses were mostly offered in English, however few of the respondents used bilingual medium of English and Urdu. 
Table 2 Profile of Interviewees

\begin{tabular}{|c|c|c|c|c|}
\hline S.No. & Gender & Education & Discipline & Teaching Experience (years) \\
\hline 1 & Male & Ph.D. & Business Administration & 5 \\
\hline 2 & Male & Ph.D. & Business Administration & 11 \\
\hline 3 & Male & Masters & Business Administration & 6 \\
\hline 4 & Female & Masters & Business Administration & 8 \\
\hline 5 & Male & Ph.D. & Business Administration & 5 \\
\hline 6 & Male & Masters & Computer Science & 16 \\
\hline 7 & Male & Masters & Computer Science & 20 \\
\hline 8 & Male & Masters & Computer Science & 5 \\
\hline 9 & Female & Ph.D. & Computer Science & 6 \\
\hline 10 & Female & Masters & Computer Science & 4 \\
\hline 11 & Male & Masters & Engineering & 7 \\
\hline 12 & Male & Masters & Engineering & 4 \\
\hline 13 & Male & Masters & Engineering & 5 \\
\hline 14 & Female & Masters & Engineering & 6 \\
\hline 15 & Male & Ph.D. & Engineering & 4 \\
\hline 16 & Female & Masters & Arts and Fashion Design & 5 \\
\hline 17 & Female & Masters & Arts and Fashion Design & 3 \\
\hline 18 & Female & Masters & Arts and Fashion Design & 8 \\
\hline 19 & Male & Masters & Arts and Fashion Design & 5 \\
\hline 20 & Male & Ph.D. & Development Studies & 3 \\
\hline 21 & Female & Masters & Development Studies & 6 \\
\hline 22 & Male & Ph.D. & Development Studies & 10 \\
\hline
\end{tabular}

\section{Research instrument}

Data was collected through semi-structured interviews from the participants in which they were asked open-ended questions. The instrument used in this study was mostly adapted from the similar previous studies conducted Hsieh and Tsai (2017); Winterhalder (2017) and Rahman \& Hameed, 2018. As suggested by Bolarinwa (2015), to establish the face validity and content validity, this instrument was shared with a panel comprising of three researchers having extensive research experience. The research instrument was finalized after incorporating the suggestions and feedback of this panel.

\section{Data coding and analysis}

A pilot test comprising of interviews from five respondents was initially conducted. The responses were recorded and transcribed. Thematic analysis was performed and results of the pilot study were compiled which were shared with few other researchers and $\mathrm{PhD}$ candidates in the department for peer review as suggested by Bitsch (2005). Such kind of feedback from the peers is particularly effective in improving the quality of research findings (Anney, 2014).

In order to improve the dependability of findings (stability of findings of over time) code-recode strategy suggested by Anney (2014) was followed. Coding of the collected data was done and then a gestation period of 2 weeks was allowed after which the 
coding of the same data was performed again to observe any differences. The coderecode strategy followed in this study resulted in almost identical results which indicate dependability of findings. Thematic analysis of the data collected through interviews was performed following six step process recommended by Braun and Clarke (2006): Extensive coding of responses was conducted to develop deeper understanding of responses, then preliminary codes were assigned to the data to describe the content, then different patterns or themes were identified, review of these themes was then conducted, prominent themes were named next and finally reported in the findings of the study. For identification of themes from the coded data we used word-based techniques: word repetitions and key-words-in-contexts (KWIC). Using these technique, key words were identified and then corpus of text was systematically searched to find all instances of each of the identified word or phrase. Each time a keyword is found, we made a copy of it and its immediate context. In this way themes were identified by physically sorting the examples into piles of similar meaning (Ryan \& Bernard, 2000).

\section{Results and discussion}

The findings of this study are covered in this section. The first question asked from the respondents was with respect to usage of Smartphones in general. The summary of responses is presented in Table 3:

As far as the general (day-to-day) usage of Smartphones is concerned, all of the respondents reported using them for communication; which included audio/video calling, sending and receiving emails and SMS. 82\% of respondents were accessing their Facebook and WhatsApp accounts using their Smartphones, while 56\% were using Twitter on their Smartphones. Smartphones are a popular gadget for entertainment and the same is observed in this study, since all the respondents were watching YouTube videos on their Smartphones as well as they were using them to capture audio/video of their events. Listening music (60\%), playing games (50\%) and reading books (41\%) were other entertainment activities in which respondents commonly engaged using their Smartphones. Moreover, they were using Smartphones for collecting and sharing information in different ways such as browsing the Internet, reading newspaper, reading blogs, and sharing posts. Existing literature on Smartphones usage indicates that Smartphones have changed the lifestyle of masses and people are increasingly becoming dependent on them. The same was observed in this study, since many respondents indicated that they were calling Careem and Uber rides, getting weather updates, getting directions using Google maps, and using calculator and calendar options of their Smartphones.

The next question posed before the respondents was related to academics related usage of Smartphones. The responses are summarized in Table 4:

Analysis of responses highlight that academics related usage of Smartphones can be divided into five major categories: sharing course materials, assessing university LMS, communicating with students, searching information and setting reminders for different tasks related to courses. Similar findings were reported by Ferry (2008) who pointed out that Smartphones can provide access to web-based content to students who can then remix it, share it with others as well as create media rich content through collaboration and share the same with their teachers and audience at large. Smartphones integration in the class is useful in enhancing individual and group learning outcomes as 
Table 3 Smartphone usage by the faculty members (in general)

\begin{tabular}{|c|c|c|c|c|}
\hline Category & Activity & $\begin{array}{l}\text { No. of } \\
\text { Respondents }\end{array}$ & $\begin{array}{l}\text { Percentage of } \\
\text { Respondents }\end{array}$ & Example of Quotations \\
\hline \multirow[t]{3}{*}{ Communication } & Audio/Video Calling & 22 & $100 \%$ & \multirow{3}{*}{$\begin{array}{l}\text { Respondent 4: "I mostly use my } \\
\text { Smartphone for email communication. } \\
\text { I find it very convenient to check email } \\
\text { while on the go or on my bed." }\end{array}$} \\
\hline & $\begin{array}{l}\text { Sending and receiving } \\
\text { Emails }\end{array}$ & 22 & $100 \%$ & \\
\hline & $\begin{array}{l}\text { Sending and receiving } \\
\text { SMS/MMS }\end{array}$ & 22 & $100 \%$ & \\
\hline \multirow[t]{3}{*}{$\begin{array}{l}\text { Social } \\
\text { Networking }\end{array}$} & Using Facebook & 18 & $82 \%$ & $\begin{array}{l}\text { Respondent 9: "We have created a } \\
\text { WhatsApp group for our department } \\
\text { and I really enjoy sharing my thoughts } \\
\text { and reading posts of the group } \\
\text { members." }\end{array}$ \\
\hline & Using Twitter & 12 & $56 \%$ & \multirow{2}{*}{$\begin{array}{l}\text { Respondent 10: "I keep myself in touch } \\
\text { with my family and friends using } \\
\text { Facebook. It is easy to share posts } \\
\text { on Facebook using my Smartphone." }\end{array}$} \\
\hline & Using WhatsApp & 18 & $82 \%$ & \\
\hline \multirow[t]{5}{*}{ Entertainment } & $\begin{array}{l}\text { Watching YouTube } \\
\text { videos }\end{array}$ & 22 & $100 \%$ & \multirow{5}{*}{$\begin{array}{l}\text { Respondent 11: "During my spare } \\
\text { time I entertain myself watching } \\
\text { videos on YouTube. I have downloaded } \\
\text { lot of my favorite songs on my } \\
\text { Smartphone and listen them while } \\
\text { jogging and lying on my bed." }\end{array}$} \\
\hline & Listening Music & 13 & $60 \%$ & \\
\hline & Playing Games & 11 & $50 \%$ & \\
\hline & Reading books & 9 & $41 \%$ & \\
\hline & $\begin{array}{l}\text { Audio/Video } \\
\text { Recording }\end{array}$ & 22 & $100 \%$ & \\
\hline \multirow[t]{4}{*}{$\begin{array}{l}\text { Collecting } \\
\text { and Sharing } \\
\text { Information }\end{array}$} & Surfing the internet & 22 & $100 \%$ & $\begin{array}{l}\text { Respondent 1: "For all my queries } \\
\text { in my daily life the first point of } \\
\text { reference is the Internet which I } \\
\text { access using my Smartphone." }\end{array}$ \\
\hline & Reading newspaper & 12 & $56 \%$ & \multirow{3}{*}{$\begin{array}{l}\text { Respondent 2: "Each morning I } \\
\text { browse headlines of all the leading } \\
\text { newspapers using my Smartphone." }\end{array}$} \\
\hline & Reading Blogs & 8 & $36 \%$ & \\
\hline & Sharing Posts & 9 & $40 \%$ & \\
\hline \multirow[t]{5}{*}{$\begin{array}{l}\text { Managing } \\
\text { daily chores }\end{array}$} & Calling Uber/Careem & 7 & $33 \%$ & $\begin{array}{l}\text { Respondent 12: "I am a frequent } \\
\text { Uber and Careem user .... I can't } \\
\text { commute without my Smartphone." }\end{array}$ \\
\hline & $\begin{array}{l}\text { Getting Weather } \\
\text { Updates }\end{array}$ & 10 & $45 \%$ & $\begin{array}{l}\text { Respondent 21: "Whenever I plan to } \\
\text { take my family for outing I get weather } \\
\text { update and directions for driving using } \\
\text { Google Maps. I really find it helpful using } \\
\text { Google maps on my Smartphone while } \\
\text { driving to new places." }\end{array}$ \\
\hline & Using Calculator & 16 & $73 \%$ & \\
\hline & Using Calendar & 13 & $60 \%$ & \\
\hline & $\begin{array}{l}\text { Using Google Maps } \\
\text { for direction }\end{array}$ & 12 & $53 \%$ & \\
\hline
\end{tabular}

well as it promotes interactive group discussions among the students (Duncan, Hoekstra, \& Wilcox, 2012). Moreover, Smartphones are very useful for teachers, since they assist teachers to control students' learning in real time (Manuguerra \& Petocz, 2011). Smartphones are very flexible; students can use them any time since they are always with student, and are always on (Kolb, 2011). Mobile phones can be used in higher education for communicating due dates of assignments, time table and any changes in class schedule (Liaw, 2008). Cui and Wang (2008) highlighted that mobile phones were effectively utilized by universities in United Kingdom for reviewing 
Table 4 Smartphone usage by the faculty members (for Academic activities)

\begin{tabular}{|c|c|c|c|c|}
\hline Category & Activity & $\begin{array}{l}\text { No. of } \\
\text { Respondents }\end{array}$ & $\begin{array}{l}\text { Percentage of } \\
\text { Respondents }\end{array}$ & Example of Quotations \\
\hline \multirow[t]{5}{*}{$\begin{array}{l}\text { Sharing Course } \\
\text { Material }\end{array}$} & $\begin{array}{l}\text { Sharing course notes } \\
\text { (Word/PDF files) }\end{array}$ & 13 & $60 \%$ & \multirow{5}{*}{$\begin{array}{l}\text { Respondent \# 18: "I rely a lot } \\
\text { on my Smartphone in sharing } \\
\text { course related material with my } \\
\text { students. I regularly share my } \\
\text { lecture notes, PowerPoint slides } \\
\text { and important announcements } \\
\text { with my students. I also share } \\
\text { YouTube videos to help them } \\
\text { understand the difficult concepts } \\
\text { covered in the class." }\end{array}$} \\
\hline & $\begin{array}{l}\text { Sharing PowerPoint } \\
\text { Presentations }\end{array}$ & 15 & $68 \%$ & \\
\hline & Sending Assignments & 12 & $55 \%$ & \\
\hline & Grading Assignments & 2 & $9 \%$ & \\
\hline & $\begin{array}{l}\text { Sharing audio/video } \\
\text { content }\end{array}$ & 6 & $27 \%$ & \\
\hline $\begin{array}{l}\text { Assessing University } \\
\text { Learning } \\
\text { Management } \\
\text { System (LMS) }\end{array}$ & & 12 & $53 \%$ & $\begin{array}{l}\text { Respondent \# 16: "Our } \\
\text { university is using Blackboard } \\
\text { LMS and I am its skillful user. } \\
\text { I share all the, assignments, } \\
\text { grades and announcements } \\
\text { with my students though LMS } \\
\text { which I generally access using } \\
\text { my Smartphone." }\end{array}$ \\
\hline \multirow[t]{4}{*}{$\begin{array}{l}\text { Communication } \\
\text { with Students }\end{array}$} & $\begin{array}{l}\text { Sending and receiving } \\
\text { SMS/MMS }\end{array}$ & 22 & $100 \%$ & $\begin{array}{l}\text { Respondent \# 9: "Every } \\
\text { semester I create a WhatsApp } \\
\text { group for each of the course I } \\
\text { teach. I have found it extremely } \\
\text { convenient and efficient medium } \\
\text { for communicating with my } \\
\text { students." }\end{array}$ \\
\hline & $\begin{array}{l}\text { Whatsapp } \\
\text { Communications }\end{array}$ & 18 & $80 \%$ & \multirow[t]{3}{*}{$\begin{array}{l}\text { Respondent \# 18: "I generally } \\
\text { encourage my students to } \\
\text { communicate using email. I } \\
\text { can check and respond to } \\
\text { their emails conveniently from } \\
\text { anywhere using my Smartphone." }\end{array}$} \\
\hline & $\begin{array}{l}\text { Sending and receiving } \\
\text { e-mails }\end{array}$ & 22 & $100 \%$ & \\
\hline & $\begin{array}{l}\text { Creating groups for } \\
\text { discussion }\end{array}$ & 6 & $27 \%$ & \\
\hline \multirow[t]{2}{*}{$\begin{array}{l}\text { Information Search } \\
\text { for Teaching }\end{array}$} & Browsing Internet & 22 & $100 \%$ & \multirow{2}{*}{$\begin{array}{l}\text { Respondent \# 1: "I am } \\
\text { teaching courses to MS/PhD } \\
\text { students for which I have to } \\
\text { search a lot of reference material. } \\
\text { My Smartphone provide me } \\
\text { internet connection on the go } \\
\text { and I can consult dictionary for } \\
\text { new and technical terms." }\end{array}$} \\
\hline & Using Dictionary & 22 & $100 \%$ & \\
\hline Reminders & $\begin{array}{l}\text { Using Calendar for } \\
\text { keeping track of } \\
\text { important events }\end{array}$ & 12 & $55 \%$ & $\begin{array}{l}\text { Respondent \# 20: ".. a lot is } \\
\text { happening each semester: } \\
\text { quizzes, assignments, mid-terms, } \\
\text { projects, etc. Smartphone is a } \\
\text { handy device to keep track of } \\
\text { all the important events." }\end{array}$ \\
\hline
\end{tabular}

students' marks and storing and retrieving information including e-books and other instructional material.

The respondents were asked to comment on the various ways in which Smartphones can be effectively used in higher education landscape. The responses are summarized in Table 5:

Smartphones offers an opportunity to keep in touch with learning even when the students walk out of school. It offers them an opportunity to continue learning their topic of interest anytime and anywhere (Hsieh \& Tsai, 2017). As indicated by the 
respondents, Smartphones are an effective tool for capturing videos and photos that they can use in their assignments and presentations. Teachers and students both can communicate with one another after duty hours for course related contents and queries. The faculty members indicated that they can recommend additional reading material, videos and blogs to help their students understand complex topics. The respondents acknowledged that Smartphones are useful tool for group learning and collaboration. In a study conducted to analyze the educator's attitude towards mobile technology, Al-Emran, Elsherif, and Shaalan (2016) reported a strong support from faculty members for using mobile devices in the education process, for communicating with students and other colleagues and for sharing educational material.

In the next question, the respondents were asked to point out some of the negative effects of using Smartphones in higher education context. The summary of responses is presented in Table 6:

The respondents highlighted different negative consequences of using Smartphones in higher education. Mainly it was indicated that Smartphones are a source of distraction because of their socializing features. Kafyulilo (2014) and Alzubi (2019) also considered distraction to be a point of concern for educators in their studies conducted in Tanzania and Saudi Arabia, respectively. Another concern expressed by the respondents

Table 5 Teachers Perceptions Regarding Effectiveness of Smartphones in Higher Education

\begin{tabular}{|c|c|c|c|c|}
\hline Category & Activity & $\begin{array}{l}\text { No. of } \\
\text { Respondents }\end{array}$ & $\begin{array}{l}\text { Percentage of } \\
\text { Respondents }\end{array}$ & Example of Quotations \\
\hline \multirow[t]{5}{*}{$\begin{array}{l}\text { Off Campus } \\
\text { Learning }\end{array}$} & Files Sharing & 12 & $53 \%$ & $\begin{array}{l}\text { Respondent \# 17: "I always encourage } \\
\text { my arts and fashion design students to } \\
\text { capture any interesting and unique } \\
\text { patterns and designs they observe } \\
\text { during any exhibition or while on the } \\
\text { go... it generally helps us in coming } \\
\text { with creative ideas,." }\end{array}$ \\
\hline & Audio/video sharing & 9 & $40 \%$ & \multirow{4}{*}{$\begin{array}{l}\text { Respondent \# 1: "I have downloaded } \\
\text { e-books of the subjects that I teach. I } \\
\text { encourage students to have an e-copy } \\
\text { of the recommended books on their } \\
\text { Smartphone which they consult when } \\
\text { ever needed." }\end{array}$} \\
\hline & $\begin{array}{l}\text { Capturing audio and } \\
\text { video for assignments } \\
\text { and presentations }\end{array}$ & 9 & $40 \%$ & \\
\hline & Learning on the go & 13 & $60 \%$ & \\
\hline & Access to e-books & 9 & $40 \%$ & \\
\hline $\begin{array}{l}\text { Communication } \\
\text { after duty hours }\end{array}$ & email/SMS/MMS & 22 & $100 \%$ & $\begin{array}{l}\text { Respondent \# 13: "... any student can } \\
\text { communicate his queries anytime via } \\
\text { SMS, email or WhatsApp and I try to } \\
\text { respond them as soon as possible." }\end{array}$ \\
\hline \multirow[t]{2}{*}{$\begin{array}{l}\text { Teaching support } \\
\text { for complex } \\
\text { topics / concepts }\end{array}$} & YouTube videos & 15 & $67 \%$ & \multirow{2}{*}{$\begin{array}{l}\text { Respondent \# 15: "I support the idea, } \\
\text { that seeing is believing, therefore I am } \\
\text { always searching for interesting videos } \\
\text { on YouTube which I recommend to my } \\
\text { students in order to clarify the } \\
\text { complicated topics. Sometimes I give } \\
\text { assignments related to these videos as } \\
\text { well." }\end{array}$} \\
\hline & $\begin{array}{l}\text { Recommending } \\
\text { readings, webpages, } \\
\text { blogs to clarify the } \\
\text { concepts }\end{array}$ & 12 & $53 \%$ & \\
\hline \multirow[t]{3}{*}{$\begin{array}{l}\text { Useful for Group } \\
\text { learning / } \\
\text { discussion }\end{array}$} & $\begin{array}{l}\text { Created Google and } \\
\text { Yahoo groups }\end{array}$ & 9 & $40 \%$ & \multirow{3}{*}{$\begin{array}{l}\text { Respondent \# 2: "I have experienced } \\
\text { that students can gain valuable } \\
\text { knowledge by following the blogs and } \\
\text { other social groups established by } \\
\text { experts and enthusiasts in certain areas. } \\
\text { I recommend some pf these blogs and } \\
\text { websites/groups to keep my students } \\
\text { updated on the events happening } \\
\text { around the world." }\end{array}$} \\
\hline & Twitter following & 6 & $27 \%$ & \\
\hline & Following Blogs & 6 & $27 \%$ & \\
\hline
\end{tabular}


was that many students are becoming victim of technostress resulting from sleep disorders due to excessive use of Smartphones. Moreover, few respondents pointed out that some students are becoming unsocial, since they avoid any face to face interaction with their peers and teachers. On the similar lines, Khan, Al-Shihi, Al-Khanjari, and Sarrab (2015) reported "anti-mobile phone sentiments" as a major barrier in adoption of Smartphones for learning. Some other negative outcomes of using mobile phones in schools include non-academic texting during class hours, flirting and watching pornographic videos through mobile phones as pointed out by Kafyulilo (2014). One of the main reason behind lack of usage of Smartphones for educational purposes is that many faculty members view mobile phones as a distracting force, the same was pointed out by Baker, Lusk, and Neuhauser (2012).

Finally, the interviewees were asked to point out some of the barriers due to which they were unable to use Smartphones for learning purposes in their domain. The responses are summarized in Table 7:

The main barriers in adoption of Smartphones for learning in higher education pointed out by respondents were lack of training, lack of knowledge, lack of incentives, time constraints, and technological constraints. Additional burden on teachers to use technology in education is perhaps the main reason for the failure of almost all such initiatives (Weinberger, 2010). Failure to train the teachers is quoted as an important reason for non-adoption of mobile-device technology by Vota (2011). Some of the Smartphone users simply use them for calling and text messaging and are not familiar with other applications supported by their Smartphones. Furthermore, small screen size of Smartphones is reported by the respondents as a discomforting factor in reading large documents (Mtega, Bernard, Msungu, \& Sanare, 2012). Lack of training and

Table 6 Teachers Perceptions Regarding Negative Effects of Using Smartphones in Higher Education

\begin{tabular}{|c|c|c|c|c|}
\hline Category & Activity & $\begin{array}{l}\text { No. of } \\
\text { Respondents }\end{array}$ & $\begin{array}{l}\text { Percentage of } \\
\text { Respondents }\end{array}$ & Example of Quotations \\
\hline Distraction & $\begin{array}{l}\text { Socializing via } \\
\text { online medium }\end{array}$ & 10 & $47 \%$ & $\begin{array}{l}\text { Respondent \# 13: "I think Smartphones have } \\
\text { reduced the students' span of concentration. } \\
\text { They have to socialize so frequently on their } \\
\text { Smartphones that they could hardly concentrate } \\
\text { on their studies continuously for few minutes" }\end{array}$ \\
\hline \multirow[t]{2}{*}{$\begin{array}{l}\text { Wastage of } \\
\text { time }\end{array}$} & Playing Games & 9 & $40 \%$ & \multirow{2}{*}{$\begin{array}{l}\text { Respondent \# 16: "Present generation is spending } \\
\text { too much time on their Smartphones ... playing } \\
\text { games, watching movies, socializing, etc. Very little } \\
\text { time is left for them to engage in other activities." }\end{array}$} \\
\hline & $\begin{array}{l}\text { Watching } \\
\text { Movies }\end{array}$ & 9 & $40 \%$ & \\
\hline $\begin{array}{l}\text { Limited } \\
\text { Learning }\end{array}$ & $\begin{array}{l}\text { Not a substitute } \\
\text { to class room } \\
\text { learning }\end{array}$ & 6 & $27 \%$ & $\begin{array}{l}\text { Respondent \# 7: ".... everything cannot be learned } \\
\text { by watching videos or listening audio. Classroom } \\
\text { provides an environment that ignite student mode } \\
\text { of enquiry and eagerness to learn which I think is } \\
\text { missing when it comes to learning using } \\
\text { Smartphones." }\end{array}$ \\
\hline $\begin{array}{l}\text { Medical } \\
\text { illnesses }\end{array}$ & Technostress & 7 & $33 \%$ & $\begin{array}{l}\text { Respondent \# 5: "My personal observation is that } \\
\text { students are stressed out because of Smartphones; } \\
\text { they get less time to sleep and perform other } \\
\text { physical activities due to which their health is also } \\
\text { deteriorating." }\end{array}$ \\
\hline $\begin{array}{l}\text { Emotional } \\
\text { Detachment }\end{array}$ & $\begin{array}{l}\text { Less physical } \\
\text { interaction }\end{array}$ & 10 & $47 \%$ & $\begin{array}{l}\text { Respondent \# 12: "I feel the bond between } \\
\text { students and teachers is becoming weak because } \\
\text { of Smartphones. e-mails and SMS are not a } \\
\text { substitute for face to face meeting between } \\
\text { a teacher and his students." }\end{array}$ \\
\hline
\end{tabular}


Table 7 Possible Barriers in Teachers' Adoption of Smartphones in Higher Education

\begin{tabular}{|c|c|c|c|c|}
\hline Category & Activity & $\begin{array}{l}\text { No. of } \\
\text { Respondents }\end{array}$ & $\begin{array}{l}\text { Percentage of } \\
\text { Respondents }\end{array}$ & Example of Quotations \\
\hline $\begin{array}{l}\text { Lack of } \\
\text { Training/ } \\
\text { Support }\end{array}$ & $\begin{array}{l}\text { Don't know many } \\
\text { functionalities of } \\
\text { Smartphones }\end{array}$ & 9 & $40 \%$ & $\begin{array}{l}\text { Respondent \# 14: "I feel I know very } \\
\text { little about Smartphone functions. } \\
\text { There should be a hands on training } \\
\text { to educate faculty on how to use } \\
\text { Smartphones in formal and informal } \\
\text { learning." }\end{array}$ \\
\hline $\begin{array}{l}\text { Lack of } \\
\text { knowledge }\end{array}$ & $\begin{array}{l}\text { Don't know how to } \\
\text { use Smartphones in } \\
\text { promoting formal } \\
\text { and informal learning }\end{array}$ & 10 & $47 \%$ & $\begin{array}{l}\text { Respondent \# 6: "I don't have much } \\
\text { idea about using Smartphones in } \\
\text { promoting learning in higher } \\
\text { education. The success stories of } \\
\text { Smartphone usage in Higher } \\
\text { Education should be shared with } \\
\text { every faculty member to motivate } \\
\text { them to use this sophisticated } \\
\text { gadget." }\end{array}$ \\
\hline $\begin{array}{l}\text { Time } \\
\text { constraints }\end{array}$ & $\begin{array}{l}\text { Using technology } \\
\text { puts additional time } \\
\text { constraints on already } \\
\text { overburdened university } \\
\text { faculty }\end{array}$ & 9 & $40 \%$ & $\begin{array}{l}\text { Respondent \# 17: "Faculty members } \\
\text { in Higher Education are already } \\
\text { overburdened and asking them to use } \\
\text { Smartphones for academic purposes } \\
\text { will put an extra burden on them." }\end{array}$ \\
\hline $\begin{array}{l}\text { Lack of } \\
\text { Incentives }\end{array}$ & $\begin{array}{l}\text { No difference among } \\
\text { the users and non-users } \\
\text { of technology in terms } \\
\text { of awards and recognition }\end{array}$ & 7 & $33 \%$ & $\begin{array}{l}\text { Respondent \# 9: "... there is no } \\
\text { difference among those using } \\
\text { technology and those who are not } \\
\text { using it in terms of rewards and } \\
\text { recognition. Use of technology in } \\
\text { Higher Education demands extra time } \\
\text { and effort which should be } \\
\text { compensated in terms of awards } \\
\text { and rewards." }\end{array}$ \\
\hline \multirow{2}{*}{$\begin{array}{l}\text { Technological } \\
\text { Constraints }\end{array}$} & Small screen size & 9 & $40 \%$ & \multirow{2}{*}{$\begin{array}{l}\text { Respondent \# 12: "I am not very } \\
\text { much comfortable in reading text on } \\
\text { small screen of Smartphones. Also } \\
\text { data entry using its small keyboard is } \\
\text { troublesome for me." }\end{array}$} \\
\hline & Small keyboard & 12 & $53 \%$ & \\
\hline
\end{tabular}

support was reported as a barrier in adoption of technology among faculty members by Al-Senaidi, Lin, and Poirot (2009) and Nikolopoulou and Gialamas (2015) in their studies. Similarly, lack of technical knowledge is also reported as a barrier in uptake of technology among teachers by Kafyulilo (2014).

Although currently many people doubt the capabilities of Smartphones in educational field mainly due to small size of screen and keypad, these technical issues will be resolved in near future due to innovation in technology such as touch screen and voice systems. Maniar (2007) observed that the learning capability of students is significantly enhanced when the screen size is more than $58 \mathrm{~mm}$ (2.28 in.) diagonally. Similarly, appropriate training and support can be very effective in transforming the learning environment into a learner-centered one (Khan et al., 2015).

\section{Contribution of study}

This study is conducted in the backdrop of wide scale adoption of Smartphones among the youth in developing countries including Pakistan. Despite the fact that Smartphones are increasingly becoming popular, their usage in higher learning landscape in developing countries is dismal. Teachers can play a vital role in promoting usage of Smartphones for learning in higher education and therefore, this study is conducted to 
explore the readiness of higher educational faculty towards adoption of Smartphones for this purpose. This study adds to the existing body of knowledge by exploring the current usage of Smartphones for general as well as educational purposes by the faculty members, their perceptions regarding effectiveness of Smartphones in promoting learning, negative effects of using Smartphones in higher learning and barriers restricting faculty members' use of Smartphones for teaching and learning.

The results of the study indicate that (generally) the faculty members considered Smartphone an effective tool for off-campus communication with students, sharing text/audio/video lecture related material and for group communication/learning. However, they expressed some concerns in promoting Smartphones for learning in higher education specifically distraction from studies, wastage of time in playing games, watching movies and listening to music. Technostress and social exclusion (in physical world) were two other main concerns related to excessive use of Smartphones. As far as the major hurdles in using Smartphones in higher education, the following were the main barriers indicated by the respondents: lack of training, lack of knowledge about different useful features of Smartphones that can be used for engaging students, lack of incentives for using technology in education, and technological constraints of Smartphones specifically the small size of their screen and keyboard.

Keeping in view the potential of Smartphones in engaging youth in learning, educational institutions should pay proper attention in preparing faculty of higher education institutions to use them to engage their students. Proper training should be offered to them to understand the potential and features of Smartphones that could be helpful in engaging students effectively. Those faculty members who are using Smartphones effectively in their course should be encouraged to share their experience and knowledge with other colleagues; as well as they should be rewarded with some token of appreciation for going extra mile. Also the educational institutions and web content developers should ensure that educational content developed for the web is appropriate for small screens of Smartphones.

\section{Limitations and future directions}

The current study provides an insight on the faculty's perception of using Smartphones in higher education context, however, it also has certain limitations. First of all, the results of this study are based on interviews conducted from 22 faculty members belonging to different departments of a private sector university. Although the samples size is very small, it is quite common in qualitative studies. The sample for this study however was carefully selected to ensure variations in responses. Another limitation of this study (as generally is the case with all perception based studies) is that the views expressed by the respondents does not necessarily mean that they actually practice what they preach. Therefore, further investigation is required to reveal the relationship between the attitude and behavior. This study has uncovered some important themes based on which a survey instrument can be developed for further studies on this topic.

Future studies can be conducted to explore the differences among faculty members based on gender, age, experience and specialization. Cross cultural studies can also be useful in understanding the differences in faculty perceptions towards affective deployment of Smartphones in higher education. 
Acknowledgements

Not Applicable.

\section{Authors' contributions}

$(\mathrm{SI}=$ SHAKEEL IQBAL; ZAB = ZEESHAN AHMED BHATTI). The research idea and design was finalized by SI and ZAB by mutual consultation. Interviews, transcription, coding and analysis was carried by SI. Results, findings, conclusion and recommendations were drafted mutually by SI and ZAB. The authors read and approved the final manuscript.

\section{Authors' information}

Shakeel lqbal is an Assistant Professor in the Department of Business Administration at Iqra University, Islamabad Campus, Islamabad, Pakistan. His doctorate is in Management Information Systems. His research focuses on adoption of mobile learning in higher education institutions. Email: shakeel_awan@iqraisb.edu.pk

Zeeshan Ahmed Bhatti is a Senior Lecturer in the Department of Operations \& Systems Management at University of Portsmouth, Portsmouth, UK. His doctorate is in Management Information Systems. He has a passion for digital and social media with a keen interest in upcoming technologies. His research mostly focuses technology use in various business functions as well as online user behavior specifically prosocial behavior on social media. Email: zeeshan.bhatti@port.ac.uk

ORCID.

Shakeel lqbal http://orcid.org/0000-0002-2001-0041

Zeeshan Ahmed Bhatti http://orcid.org/0000-0003-0725-7039

\section{Funding}

Not applicable. Not funded by any external sources.

\section{Availability of data and materials}

The datasets used and/or analyzed during the current study are available from the corresponding author on reasonable request.

\section{Competing interests}

The authors declare that they have no competing interests.

\section{Author details}

${ }^{1}$ Department of Business Administration, Iqra University Islamabad Campus, Islamabad, Pakistan. ${ }^{2}$ Department of Operations \& Systems Management, Faculty of Business \& Law, University of Portsmouth, Portsmouth, UK.

Received: 9 January 2020 Accepted: 14 April 2020

Published online: 06 July 2020

\section{References}

Al-Emran, M., Elsherif, H. M., \& Shaalan, K. (2016). Investigating attitudes towards the use of mobile learning in higher education. Computers in Human Behavior, 56, 93-102.

Alexander, B. (2004). Going nomadic: Mobile learning in higher education. Educause Review, 39(5), 28-35.

Al-Senaidi, S., Lin, L., \& Poirot, J. (2009). Barriers to adopting technology for teaching and learning in Oman. Computers \& Education, 53(3), 575-590.

Alzubi, A. (2019). Teachers' perceptions on using smartphones in English as a foreign language context. Research in Social Sciences and Technology, 4(1), 92-104.

Angeli, C., Valanides, N., \& Bonk, C. J. (2003). Communication in a web-based conferencing system: The quality of computermediated interaction. British Journal of Educational Technology, 34(1), 31-43.

Anney, V. N. (2014). Ensuring the quality of the findings of qualitative research: Looking at trustworthiness criteria. Journal of Emerging Trends in Educational Research and Policy Studies (JETERAPS), 5(2), 272-281.

Awedh, M., Mueen, A., Zafar, B., \& Manzoor, U. (2015). Using Socrative and smartphones for the support of collaborative learning arXiv preprint arXiv:1501.01276.

Baker, W. M., Lusk, E. J., \& Neuhauser, K. L. (2012). On the use of cell phones and other electronic devices in the classroom: Evidence from a survey of faculty and students. Journal of Education for Business, 87(5), 275-289.

Bitsch, V. (2005). Qualitative research: A grounded theory example and evaluation criteria. Journal of Agribusiness, 23(1), 75-91.

Bolarinwa, O. A. (2015). Principles and methods of validity and reliability testing of questionnaires used in social and health science researches. The Nigerian Postgraduate Medical Journal, 22(4), 195.

Braun, V., \& Clarke, V. (2006). Using thematic analysis in psychology. Qualitative Research in Psychology, 3(2), 77-101.

Brookhart, S. M., \& Freeman, D. J. (1992). Characteristics of entering teacher candidates. Review of Educational Research, 62, 3760.

Brown, T. H. (2005). Towards a model for m-learning in. Africa International Journal on E-learning, 4(3), 299-315.

Buck, J. L., Mclnnis, E., \& Randolph, C. (2013). The new frontier of education: The impact of smartphone technology in the classroom. In American Society for Engineering Education.

Butt, I. H., \& Qaisar, S. (2017). Readiness of Pakistani University teachers and students for M-learning in a Public University. Journal of Research \& Reflections in Education (JRRE), 11(1), 86-96.

Carr, N. (2011). The shallows: What the internet is doing to our brains. WW Norton \& Company, New York/London.

Cui, G., \& Wang, S. (2008). Adopting cell phones in EFL teaching and learning. Journal of Educational Technology Development and Exchange (JETDE), $1(1), 6$.

Duncan, D. K., Hoekstra, A. R., \& Wilcox, B. R. (2012). Digital devices, distraction and student performance-does cell phone use reduce learning? In American astronomical society meeting abstracts\# 219 (Vol. 219). 
Ferry, B. (2008). Using mobile phones to augment teacher learning in environmental education. In Hello! Where are you in the landscape of educational technology? Proceedings ascilite Melbourne 2008. http://www.ascilite.org.au/conferences/ melbourne08/procs/ferry.pdf.

Hsieh, W. M., \& Tsai, C. C. (2017). Taiwanese high school teachers' conceptions of mobile learning. Computers \& Education, $115,82-95$.

labal, S., Khan, M. N., \& Malik, I. R. (2017). Mobile phone usage and students' perception towards M-learning: A case of undergraduate students in Pakistan. International Journal of E-Learning \& Distance Education, 32(1). 1-16.

Iqbal, S., \& Qureshi, I. A. (2012). M-learning adoption: A perspective from a developing country. The International Review of Research in Open and Distributed Learning, 13(3), 147-164.

Kafyulilo, A. (2014). Access, use and perceptions of teachers and students towards mobile phones as a tool for teaching and learning in Tanzania. Education and Information Technologies, 19(1), 115-127.

Kennedy, G., \& Cuts, Q. (2005). The association between students use and electronic voting system and their learning outcomes. Journal of Computer Assisted Learning, 21, 260-268.

Khan, A. A., Khalid, A., \& lqbal, R. (2019). Revealing the relationship between smartphone addiction and academic performance of students: Evidences from higher educational Institutes of Pakistan. Pakistan Administrative Review, 3(2), 74-83.

Khan, A. I., Al-Shihi, H., Al-Khanjari, Z. A., \& Sarrab, M. (2015). Mobile learning (M-learning) adoption in the Middle East: Lessons learned from the educationally advanced countries. Telematics and Informatics, 32(4), 909-920.

Kibona, L., \& Rugina, J. M. (2015). A review on the impact of smartphones on academic performance of students in higher learning institutions in Tanzania. Journal of Multidisciplinary Engineering Science and Technology, 2, 673-677.

Kolb, L. (2011). Adventures with cell phones. Educational Leadership, 68(5), 39-43.

Lantz, M. E. (2010). The use of 'clickers' in the classroom: Teaching innovation or merely an amusing novelty? Computers in Human Behavior, 26(4), 556-561.

Leem, J., \& Sung, E. (2019). Teachers' beliefs and technology acceptance concerning SMART mobile devices for SMART education in South Korea. British Journal of Educational Technology, 50(2), 601-613.

Liaw, S. S. (2008). Investigating students' perceived satisfaction, behavioral intention, and effectiveness of e-learning: A case study of the blackboard system. Computers \& Education, 51(2), 864-873.

Lipponen, L. (2002). Exploring foundations for computer-supported collaborative learning. In G. Stahl (Ed.), 4th CSCL: Foundations for a CSCL community (CSCL-2002), (pp. 72-81). Colorado: LEA.

Litchfield, S. (2010). Defining the smartphone Retrieved 20 October 2018 from http://www.allaboutsymbian.com/features/item/ Defining_the_Smartphone.php.

Manuguerra, M., \& Petocz, P. (2011). Promoting student engagement by integrating new technology into tertiary education: The role of the iPad. Asian Social Science, $7(11), 61$.

Marshall, B., Cardon, P., Poddar, A., \& Fontenot, R. (2013). Does sample size matter in qualitative research? A review of qualitative interviews in IS research. Journal of Computer Information Systems, 54(1), 11-22.

Mehdipour, Y., \& Zerehkafi, H. (2013). Mobile learning for education: Benefits and challenges. International Journal of Computational Engineering Research, 3(6), 93-101.

Miglani, A., \& Awadhiya, A. K. (2017). Mobile learning: Readiness and perceptions of teachers of open universities of commonwealth Asia. Journal of learning for development-JL4D, 4(1), 58-71.

Mtega, W. P., Bernard, R., Msungu, A. C., \& Sanare, R. (2012). Using mobile phones for teaching and learning purposes in higher learning institutions: The case of Sokoine University of agriculture in Tanzania. Wulystan. In Proceedings and report of the 5th UbuntuNet Alliance annual conference, (pp. 118-129).

Nand, S., Pitafi, A. H., Kanwal, S., Pitafi, A., \& Rasheed, M. I. (2019). Understanding the academic learning of university students using smartphone: Evidence from Pakistan. Journal of Public Affairs, e1976. Retrieved online 02 May 2020 from https:// onlinelibrary.wiley.com/doi/abs/10.1002/pa.1976.

Nikolopoulou, K., \& Gialamas, V. (2015). Barriers to the integration of computers in early childhood settings: Teachers' perceptions. Education and Information Technologies, 20(2), 285-301.

O'Malley, C., Vavoula, G., Glew, J. P., Taylor, J., Sharples, M., Lefrere, P., ... Waycott, J. (2005). Guidelines for learning/teaching/ tutoring in a mobile environment Retrieved October 1, 2018 from https://hal.archives-ouvertes.fr/hal-00696244/document.

Panitz, T. (1996). A definition of collaborative versus cooperative learning Retrieved 01 October 2018 from http://colccti. colfinder.org/sites/default/files/a_definition_of_collaborative_vs_cooperative_learning.pdf.

Park, Y. (2011). A pedagogical framework for mobile learning: Categorizing educational applications of mobile technologies into four types. The International Review of Research in Open and Distributed Learning, 12(2), 78-102.

Rahman, H., \& Hameed, M. (2018). Teaching and learning with smartphone: Qualitative explorative study from Pakistan. In 4th international conference on higher education advances (HEAD'18), (pp. 471-478) Editorial Universitat Politècnica de València.

Richardson, J. T. (1996). Handbook of qualitative research methods for psychology and the social sciences. Leicester: BPS Books.

Russell, C. K., \& Gregory, D. M. (2003). Evaluation of qualitative research studies. Evidence-Based Nursing, 6(2), 36-40.

Ryan, G. W., \& Bernard, H. R. (2000). Techniques to identify themes in qualitative data. Handbook of qualitative research, (2nd ed., ). Thousand Oaks: Sage Publications.

Schuler, C., Winters, N., \& West, M. (2012). The future of mobile learning: Implications for policy makers and planners. Paris: UNESCO.

Schutt, R. K. (2006). Investigating the social world: The process and practice of research, (5th ed., ). Thousand Oaks: Pine Forge.

Shraim, K., \& Crompton, H. (2015). Perceptions of using smart mobile devices in higher education teaching: A case study from Palestine. Contemporary Educational Technology, 6(4), 301-318.

Slauenwhite, C. A., \& Simpson, P. (1998). Patient and family perspectives on early discharge and care of the older adult undergoing fractured hp rehabilitation. Orthopaedic Nursing, 17(1), 30.

Teddlie, C., \& Yu, F. (2007). Mixed methods sampling. Journal of Mixed Methods Research, 1(1), 77-100. https://doi.org/10.1177/ 2345678906292430 .

Trinder, J. (2005). Mobile technologies and systems. In A. Kuklska-Hulme (Ed.), Mobile learning: A handbook for educators and trainers. New York: Taylor \& Francis. 
Vota, W. (2011). Tablets are good, content is better, and teachers are the best educational ICT investment. In Tablet computers in education Retrieved 1 November 2018 from http://edutechdebate.org/tablet-computers-in-education/tablets-are-goodcontent-is-better-and-teachers-are-the-best-educational-ict-investment/.

Weinberger, S. (2010). TeacherMate: Individualized. In Teacher-assisted instruction. Low-cost ICT devices. Exploring ICT and learning in developing countries Retrieved 1 November 2018 from http://edutechdebate.org/low-cost-ict-devices/ teachermate-individualized-teacher-assisted-instruction/.

Winterhalder, J. (2017). Teachers' perceptions and experiences in implementing Mobile devices into their teaching Doctoral dissertation, Walden University.

Yahya, S., Ahmad, E. A., \& Jalil, K. A. (2010). The definition and characteristics of ubiquitous learning: A discussion. International Journal of Education and Development using Information and Communication Technology, 6(1), 1.

Yoder, J. D., \& Hochevar, C. M. (2005). Encouraging active learning can improve students' performance on examinations. Teaching of Psychology, 32, 91-95.

Maniar, N. (2007). M-learning to teach university students. In C. Montgomerie \& J. Seale (Eds.), Proceedings of ED-MEDIA 2007--World Conference on Educational Multimedia, Hypermedia \& Telecommunications (pp. 881-887). Vancouver: Association for the Advancement of Computing in Education (AACE). Retrieved May 2, 2020 from https://www. learntechlib.org/primary/p/25485/.

\section{Publisher's Note}

Springer Nature remains neutral with regard to jurisdictional claims in published maps and institutional affiliations.

Submit your manuscript to a SpringerOpen ${ }^{\circ}$ journal and benefit from:

- Convenient online submission

- Rigorous peer review

- Open access: articles freely available online

High visibility within the field

Retaining the copyright to your article

Submit your next manuscript at $>$ springeropen.com 